\title{
Presence of HPV, EBV and HMTV Viruses Among Egyptian Breast Cancer Women: Molecular Detection and Clinical Relevance
}

\author{
Shimaa A Metwally (D) \\ Maha A Abo-Shadi (D) \\ Nasra F Abdel Fattah ${ }^{2}$ \\ Ahmed B Barakat ${ }^{3}$ \\ Omar A Rabee ${ }^{3}$ \\ Ahmed M Osman (iD ${ }^{2}$ \\ Amany $\mathrm{M} \mathrm{Helal}^{4}$ \\ Tarek Hashem ${ }^{5}$ \\ Manar M Moneer 6 \\ Wassim Chehadeh (iD ${ }^{7}$ \\ Samah A Loutfy (iD ${ }^{2,8}$ \\ 'Microbiology \& Immunology \\ Department, Faculty of Pharmacy for \\ Girls, Al-Azhar University, Cairo, Egypt; \\ ${ }^{2}$ Virology and Immunology Unit, Cancer \\ Biology Department, National Cancer \\ Institute (NCl), Cairo University, Cairo, \\ Egypt; ${ }^{3}$ Microbiology Department, \\ Faculty of Science, Ain Shams University, \\ Cairo, Egypt; ${ }^{4}$ Medical Oncology \\ Department, National Cancer Institute, \\ Cairo University, Cairo, Egypt; ${ }^{5}$ Surgical \\ Oncology Department, National Cancer \\ Institute, Cairo University, Cairo, Egypt; \\ ${ }^{6}$ Cancer Epidemiology and Biostatistics \\ Department, National Cancer Institute, \\ Cairo University, Cairo, Egypt; \\ ${ }^{7}$ Department of Microbiology, Faculty of \\ Medicine, Kuwait University, Jabriya, \\ Kuwait; ${ }^{8}$ Nanotechnology Research \\ Center, British University in Egypt (BUE), \\ Cairo, Egypt
}

Correspondence: Samah A Loutfy Virology and Immunology Unit, Cancer Biology Department, National Cancer Institute (NCl), Cairo University, Cairo, Egypt

Tel +20I 222840964

Email samah.loutfy@gmail.com
Background: Oncogenic viruses, their possible association with breast cancer (BC) and effect on its clinical course are interesting issue. The present study evaluates the presence of human papillomavirus (HPV), EpsteinBarr virus (EBV), and human mammary tumor virus (HMTV) in BC and their relation with clinico-pathological characteristics.

Patients and Methods: This study was conducted on 80 Egyptian women with $\mathrm{BC}$ and 30 control women without known oncological disease. Forty formalin-fixed paraffin-embedded (FFPE) tissues, forty fresh tissue samples, and white blood cells (WBCs) of BC patients and WBCs of controls were subjected to a qualitative polymerase chain reaction (PCR). Quantitative real-time PCR was used to measure viral loads in fresh tissues of BC. The result was correlated with clinico-pathological characteristics of $\mathrm{BC}$.

Results: HPV was detected in $33(41.25 \%)$, EBV in $30(37.5 \%)$ and HMTV in 33 $(41.25 \%)$ BC patients. None of the control women was positive for HPV or EBV while HMTV was detected in 7 (23.3\%). Among 40 BC WBCs specimens, HPV/HMTV were found together in 25\%, followed by EBV/HMTV in 2.5\% and EBV/HPV in $2.5 \%$. However, the three viruses (HPV/EBV/HMTV) were found together in only 5\%. In the 40 fresh BC tissues, the three viruses were found together in 12 (30\%), EBV/HMTV in 7 (17.5\%), HPV/ HMTV in $4(10 \%)$, and HPV/EBV in $4(10 \%)$. EBV, HMTV, or multiple viral infections were associated with younger age of BC women. HPV, EBV, and HMTV median loads in fresh tissues were $4.8 \times 10^{3}$ copies $/ \mu \mathrm{L}, 6.3 \times 10^{3}$ copies $/ \mu \mathrm{L}$, and 97 copies $/ \mu \mathrm{L}$, respectively.

Conclusion: WBCs could be a more suitable specimen instead of fresh tissue for HMTV detection in BC patients to avoid invasive procedures. The presence of HPV, EBV, and HMTV together in Egyptian women with BC was significantly associated with younger age. Keywords: HPV, EBV, HMTV, young age, breast cancer, quantitative real-time PCR, viral load

\section{Introduction}

New breast cancer (BC) cases among Egyptian females in 2020 were 22,038, representing 32.4\% among other cancer types with $10.3 \%$ deaths. ${ }^{1}$ Human Papillomavirus (HPV), EpsteinBarr virus (EBV), and Human Mammary Tumor virus (HMTV) were suggested to have a possible relationship to BC. ${ }^{2,3}$ Simões and co-workers ${ }^{4}$ summarized 29 studies including 2211 breast tissue samples from different geographical regions. They found that $23 \%$ of BC patients had HPV DNA. Besides, HMTV was reported in a wide range $(0-78 \%)$ of numerous populations with $\mathrm{BCs}{ }^{5}$ Prevalence range of EBV infection among $\mathrm{BC}$ cases of 26 countries was $0-78.12 \%{ }^{6}$ 
Individuals with $\mathrm{BC}$ may become immune-compromised due to $\mathrm{BC}$ disease itself or chemotherapy and radiotherapy. Hence, they might be more vulnerable to viral infections that can aggravate the disease. ${ }^{7}$ For example, HPV Early 6/Early 7 (E6/E7) oncoproteins can convert non-invasive and nonmetastatic BC cells into invasive and metastatic forms. ${ }^{8}$ Also, the presence of HPV in BC patients was associated with increased inflammatory cytokines, tumor progression, ${ }^{9}$ and younger age. ${ }^{10}$ HMTV showed higher positivity in patients with advanced (grade 3) BC disease ${ }^{11}$ and was correlated with estrogen and human epidermal growth factor receptor 2 (her2/ neu) expression and metastasis in these patients. ${ }^{12}$ Many studies have reported an association of EBV with lymph node metastasis and more aggressive behavior of the tumor. ${ }^{13-15}$ Moreover, HPV, EBV, and MMTV presence was previously reported to be associated with increased-grade in human BCs. ${ }^{16}$

It was previously reported that HMTV could be detected together with HPV and EBV in the same BC cells. ${ }^{16}$ Therefore, HPV, EBV, and HMTV alone or together in the same BC patient were highly suggested to cause $\mathrm{BC}$ disease aggressiveness. Limited reports from the Arab world on the coprevalence of HPV, EBV, and HMTV and their clinical relevance in $\mathrm{BC}$ patients were found. The different reviewed literature included HPV and EBV together. Still, they did not investigate their co-prevalence with HMTV or their association with clinico-pathological characteristics of $\mathrm{BC}$ disease, such as studies conducted on Syrian BC women ${ }^{17}$ and Egyptian BC women. ${ }^{18,19}$ In addition, another study detected HPV, EBV, and HMTV in Egyptian BC women, but it did not investigate their association with clinico-pathological characteristics of $\mathrm{BC}$ disease. ${ }^{20}$

$\mathrm{BC}$ disease management and understanding its behavior requires extensive study of the association between environmental factors that may affect the pathogenesis of $\mathrm{BC}$ disease (especially viral infection) and their association with patient's clinico-pathological parameters. The current study aimed to evaluate the frequency of HPV, EBV, and HMTV alone or together in different samples of $\mathrm{BC}$ disease and their association with some clinical and pathological characteristics as a possible indicator of $\mathrm{BC}$ patients at a higher risk to develop severe disease.

\section{Patients and Methods}

\section{Patients}

This study was conducted on $80 \mathrm{BC}$ patients diagnosed and treated at the medical oncology department, National
Cancer Institute (NCI), Cairo University, between July 2018 and June 2020. Thirty normal control women without known oncological disease and with comparable age were included as a control group. The Institutional Review Board (IRB) of the NCI approved the protocol IRP NO. (201819039.3). Informed consent was taken from all participants who joined the study. Women suffering from $\mathrm{BC}$ and who had not received any chemotherapy treatment before surgery were the inclusion criteria.

\section{Collection of Patients' Data}

The patients' data were collected from their medical files kept in the biostatistics and epidemiology department, NCI, Cairo University. Data extracted were age at diagnosis, family history of $\mathrm{BC}$, diagnosis, lymph node metastasis, tumor size, histologic grade, laterality, hormonal receptor status including estrogen receptor (ER), progesterone receptor (PR), and human epidermal growth factor receptor 2 (HER2). Histologic type and histological grade were evaluated consistently with the previous protocols. ${ }^{21,22}$

\section{Specimen Collection}

Five $\mathrm{mL}$ of whole blood and $250 \mathrm{mg}$ of fresh tissues were collected from $40 \mathrm{BC}$ patients. In addition, $250 \mathrm{mg}$ of formalin-fixed and paraffin-embedded (FFPE) tissue were collected from another $40 \mathrm{BC}$ women. Five $\mathrm{mL}$ of whole blood were obtained from 30 controls. Tissue analysis was limited to core biopsies only. White blood cells (WBCs) were separated from blood samples according to the previously published protocols ${ }^{23,24}$ while processing, tissues, and $\mathrm{WBCs}$ were stored at $-80^{\circ} \mathrm{C}$.

\section{Nucleic Acid Extraction}

Viral DNAs were extracted from WBCs using QIAamp viral RNA extraction kit (Qiagen, Valencia, USA), which can extract both viral DNAs and RNAs. Genomic DNAs were extracted from fresh and FFPE tissues using Gene JET Genomic DNA Purification Kit (Thermo Scientific, Inc, USA) and QIAamp DNA FFPE Tissue Kit (Qiagen, Valencia, USA), respectively, according to the manufacturer's instructions. A Nano-Drop 2000 spectrophotometer (Thermo Scientific/US, Canada) was used to assess the quality and quantity of isolated viral and total genomic DNAs. $100 \mathrm{ng}$ of DNA templates were used in each Polymerase chain reaction (PCR) assay. DNA extracts were stored at $-80{ }^{\circ} \mathrm{C}$ till further analysis. 


\section{Molecular Detection of Viral DNAs}

Every feasible precaution was taken to avoid contamination of the analyzed samples whether in qualitative or quantitative PCR assays. These precautions included work in separate areas with a one-way direction using appropriate personal protective equipment (PPE) for; sample processing, pre-amplification, and post-amplification. Besides, all the used equipment and surfaces were continuously decontaminated, all samples were stored separately from kits and reagents. Also, precautions like dispensing reagents into aliquots, using pipettes with barrier tips, and changing gloves before dealing with any of the samples, were implemented. Finally, the result was validated and reported after validating positive and negative controls.

\section{Qualitative PCR}

All extracted DNAs from patients (FFPE tissues, fresh tissues and WBCs) and controls (WBCs) were subjected to qualitative conventional PCR assay targeting HPV Late 1 (L1) region detection, EBV Bam $\mathrm{H} 1 \mathrm{~W}$ region detection, and HMTV envelope (env) gene detection. The amplification was conducted in a final volume of $25 \mu \mathrm{L}$ of $1 \mathrm{X}$ AmpliTaq PCR master mix (Biosystems, Barcelona, Spain) and 0.2 $\mu \mathrm{M}$ of both forward and reverse primers for each virus, using thermal cycling block (Applied Biosystems ${ }^{\mathrm{TM}}$ ProFlex $^{\mathrm{TM}}$ PCR System, USA). Nuclease-free water was used to make up the volume. Primers used in the molecular assays are presented in Table 1. The PCR reaction amplification conditions for HPV, EBV, and HMTV were carried out according to previously published protocols. ${ }^{25-28}$

PCR reaction mixture without template DNA was used as a negative control sample in each PCR run. EBV (American Type Culture Collection $\left(\mathrm{ATCC}^{\circledR}\right)$ VR$1492^{\text {TM }}$ ) was used as a positive control for EBV. HPV \&
HMTV DNAs were extracted in NCI virology laboratory from Michigan Cancer Foundation-7 (MCF7) cells ${ }^{28-30}$ (ATCC $^{\circledR}$ HTB-22 ${ }^{\text {TM}}$ ) obtained from Egyptian Holding Company for Biological Products \& Vaccines (VACSERA) using the same extraction procedure for samples. HPV positive control was confirmed as HPV type 18 by PCR using a linear array HPV genotyping kit (Roche Diagnostics, Indianapolis, IN, USA).

Seventeen $\mu \mathrm{L}$ of each PCR product were electrophoresed on a $2 \%$ agarose gel (Sigma) in Tris-acetate buffer (TAE 1X) and then stained with $0.5 \mu \mathrm{g} / \mathrm{mL}$ ethidium bromide, examined under Ultra Violet (UV) transillumination and photographed. The product sizes were compared against 100 bp DNA ladder (Genedirex, Taiwan).

Specificity of qualitative PCR for detection of HPV, EBV, and HMTV DNAs was performed by testing samples positive for the following viruses; Herpes Simplex Virus 1 (HSV1), Herpes Simplex Virus 2 (HSV2), Adenovirus (Adv.), HMTV, HPV, Cytomegalovirus (CMV) and EBV, according to the tested virus. Then, qualitative PCR assay was performed according to the previously published protocols. $^{25-28}$

\section{Quantitative Real-Time PCR}

HPV, EBV, and HMTV viral loads were measured in fresh tissues by a quantitative real-time detection system (Applied Biosystems 7500 Fast Real-Time PCR system Thermal Cycling Block, USA). The amplification was conducted in a final volume of $25 \mu \mathrm{L}$ containing $1 \mathrm{X}$ Qiagen Sybrgreen ${ }^{\circledR}$ PCR Master Mix kit (Qiagen, Valencia, USA), $0.2 \mu \mathrm{M}$ of each forward and reverse primer for each virus, and 100ng of extracted DNA. Nuclease-free water was used to make up the volume.

Table I Sequences of Primers Used for Human Papillomavirus (HPV), EpsteinBarr Virus (EBV) and Human Mammary Tumor Virus (HMTV) by Both Qualitative and Quantitative Polymerase Chain Reaction (PCR)

\begin{tabular}{|c|c|c|c|c|c|}
\hline Virus & $\begin{array}{c}\text { GenBank Accession } \\
\text { Number }\end{array}$ & Sequences $\left(5^{\prime}-3^{\prime}\right)$ & $\begin{array}{l}\text { Nucleotide } \\
\text { Position }\end{array}$ & $\begin{array}{l}\text { Amplicon } \\
\text { Size }\end{array}$ & References \\
\hline \multirow[t]{2}{*}{ HPV } & \multirow[t]{2}{*}{ NC_001357.I } & (MYII): 5'-CGT CCM ARR GGA WAC TGATC-3' & \multirow{2}{*}{$\begin{array}{c}\text { On HPV I8: } 6559 \\
\text { to } 7013\end{array}$} & \multirow[t]{2}{*}{$450 \mathrm{bp}$} & \multirow[t]{2}{*}{ [25] } \\
\hline & & (MY09): 5'-GCM CAG GGW CAT AAY AATGG-3' & & & \\
\hline \multirow[t]{2}{*}{ EBV } & \multirow[t]{2}{*}{ NC_007605.I } & (EBI): 5'-CAC TTT AGA GCT CTG GAG GA-3' & \multirow[t]{2}{*}{17,098 to 17,250} & \multirow[t]{2}{*}{$153 \mathrm{bp}$} & \multirow[t]{2}{*}{ [26] } \\
\hline & & (EB2): 5'-TAA AGA TAG CAG CAG CGC AG-3' & & & \\
\hline \multirow[t]{2}{*}{ HMTV } & \multirow[t]{2}{*}{ K00556.I } & $(2 N): 5^{\prime}-C C T$ ACA TCT GCC TGT GTT AC-3' & \multirow[t]{2}{*}{1386 to 1640} & \multirow[t]{2}{*}{$254 \mathrm{bp}$} & \multirow[t]{2}{*}{ [28] } \\
\hline & & $(3 N):$ 5'-ATC TGT GGC ATA CCT AAA GG-3' & & & \\
\hline
\end{tabular}


Thermal cycling was performed as mentioned before in qualitative PCR assay.

Threshold cycle $(\mathrm{Ct})$ value was detected for each sample, and viral load was calculated. Post amplification melting temperature $(\mathrm{Tm})$ analysis, together with gel electrophoresis, clearly differentiated nonspecific PCR products from the HPV, EBV, or HMTV specific product sequences. Standard curves were constructed using 10-fold serial dilutions (10 to $10^{6}$ copies $/ \mu \mathrm{L}$ ) of HPV, EBV, or HMTV positive controls with known concentrations of 300 FG of extracted DNA equivalent to one copy of viral DNA.

\section{Statistical Methods}

Sample size calculation: the total number of cases that attended NCI with BC was estimated to be 2500 per year. A previous study conducted in Egypt by El-Sheshtawy et al $(2017)^{31}$ indicated that the overall prevalence of HPV in malignant breast tissue was $16.7 \%$. For a twosided $95 \%$ confidence interval for a single proportion based on these criteria, the minimum required sample size to evaluate the practice was 54 cases with a $10 \%$ margin of error. To compensate for possible loss, the sample increased by $10 \%$. Therefore, a sample of 60 cases was estimated. The sample size was calculated using the n-Query statistical package. ${ }^{32}$

Statistical analysis was done using IBM SPSS $^{\circledR}$ Statistics version 22 (IBM ${ }^{\circledR}$ Corp., Armonk, NY, USA). Qualitative data were expressed as frequency and percentage. Pearson's Chi-square test or Fisher's exact test was used for examining the relationship between qualitative variables. Kappa test was used to evaluate the agreement of detection of viruses in fresh tissues and WBCs. Numerical data were expressed as mean and standard deviation or median and range. Comparison between two groups for numerical variables was made using either the Student- $t$-test or Mann-Whitney test according to distribution. A p-value $<0.05$ was considered significant.

\section{Result}

\section{Clinico-Pathological Findings}

All studied BC patients $(n=80)$ had a unilateral BC. Out of eighty $\mathrm{BC}$ patients, 34 (42.5\%) were familial BC, including $24 \mathrm{BC}$ patients with blood samples. Regarding $\mathrm{BC}$ disease characteristics, all BCs were diagnosed as invasive carcinoma (lobular or ductal), and 75/ $80(93.8 \%)$ were classified as grade II tumors. The median tumor size was $2.5 \mathrm{~cm}$, and the most observed was positivity for ER and PR hormonal receptors expression as observed in $70 / 80(87.5 \%)$ and $72 / 80(90 \%)$ of $\mathrm{BC}$ patients, respectively. Lymph node metastasis was found in $47 / 80(58.8 \%)$ of patients. All pathological findings of BC patients are summarized in Table 2.

The mean age of the $80 \mathrm{BC}$ patients was $41.3 \pm 9.2$ years and $39.9 \pm 11.2$ for the healthy controls, $\mathrm{P}=0.207$. The forty $\mathrm{BC}$ women (with blood samples) and 30 control women were age-matched with no statistical difference $(\mathrm{P}=0.591)$. Besides, the two subgroups (FFPE and fresh tissue samples) of $\mathrm{BC}$ patients were comparable in age with a mean (38.6 \pm 6.7 years vs $41.3 \pm 9.2$, respectively, $\mathrm{P}=0.140$ ).

\section{Presence of HPV, EBV and HMTV DNAs in Studied Groups as Detected by Qualitative PCR Assay}

Taking all $80 \mathrm{BC}$ women, HPV and HMTV were the most frequent viruses detected in $\mathrm{BC}$ specimens $(33 / 80,41.25 \%)$, followed by EBV (30/80, 37.5\%) (Table S1). The detection

Table 2 Pathological Findings of Breast Cancer (BC) Patients

\begin{tabular}{|c|c|c|c|c|}
\hline \multirow{3}{*}{\multicolumn{2}{|c|}{$\begin{array}{l}\text { Pathological } \\
\text { Parameters }\end{array}$}} & BC Group & BC Group & $\begin{array}{l}\text { Total BC } \\
\text { Group }\end{array}$ \\
\hline & & $N=40$ & $N=40$ & $\mathbf{N}=\mathbf{8 0}$ \\
\hline & & $\begin{array}{c}\text { (Fresh Tissues } \\
\text { and WBCs) } \\
\text { N (\%) }\end{array}$ & $\begin{array}{c}\text { (FFPE } \\
\text { Tissues) } \\
\text { N (\%) }\end{array}$ & $\mathbf{N}(\%)$ \\
\hline \multicolumn{5}{|l|}{ Tumor size } \\
\hline \multicolumn{2}{|l|}{ Median } & $2.5 \mathrm{~cm}$ & $2.5 \mathrm{~cm}$ & $2.5 \mathrm{~cm}$ \\
\hline \multicolumn{2}{|l|}{ (range) } & $(1.5-8.5) \mathrm{cm}$ & $(0.7-5.5) \mathrm{cm}$ & $(0.7-8.5) \mathrm{cm}$ \\
\hline \multicolumn{2}{|l|}{$>2.5 \mathrm{~cm}$} & 19 (47.5\%) & $20(50 \%)$ & 39 (48.8\%) \\
\hline \multicolumn{2}{|l|}{$\leq 2.5 \mathrm{~cm}$} & $2 \mathrm{I}(52.5 \%)$ & $20(50 \%)$ & $4 I(5 I .2 \%)$ \\
\hline \multicolumn{5}{|c|}{ Lymph node metastasis } \\
\hline \multicolumn{2}{|l|}{ Positive } & 19 (47.5\%) & 28 (70\%) & 47 (58.8\%) \\
\hline \multicolumn{2}{|l|}{ Negative } & 21 (52.5\%) & $12(30 \%)$ & $33(41.3 \%)$ \\
\hline \multirow{9}{*}{$\begin{array}{l}\text { Hormonal } \\
\text { receptors }\end{array}$} & \multicolumn{4}{|c|}{ ER } \\
\hline & Positive & 35 (87.5\%) & 35 (87.5\%) & 70 (87.5\%) \\
\hline & Negative & 5 (12.5\%) & 5 (12.5\%) & 10 (I2.5\%) \\
\hline & \multicolumn{4}{|c|}{$\mathrm{PR}$} \\
\hline & Positive & 35 (87.5\%) & 37 (92.5\%) & 72 (90\%) \\
\hline & Negative & 5 (12.5\%) & $3(7.5 \%)$ & $8(10 \%)$ \\
\hline & \multicolumn{4}{|c|}{ HER2 } \\
\hline & Positive & 22 (55\%) & 17 (42.5\%) & 39 (42.5\%) \\
\hline & Negative & 18 (45\%) & 23 (57.5\%) & $4 \mathrm{I}(5 \mathrm{I} .2 \%)$ \\
\hline
\end{tabular}

Abbreviations: N, number; WBCs, white blood cells; FFPE, formalin fixed paraffin embedded; ER, estrogen receptor; PR, progesterone receptor; HER2, human epidermal growth factor receptor 2 ; $\mathrm{cm}$, centimeter. 
of HPV, EBV, and HMTV DNAs, was significantly lower in FFPE tissues than in fresh tissue samples of $\mathrm{BC}$ patients. Therefore, data of FFPE tissues were not included in further analysis. Data are demonstrated in Table 3.

Regarding WBCs of BC patients and controls, HPV, EBV, and HMTV DNAs were detected in 40\%, 10\%, and $57.5 \%$ of BC patients, respectively. Only HMTV was detected in $23.3 \%$ of healthy controls. Comparison of presence of viruses between $\mathrm{BC}$ and healthy control women showed $\mathrm{P}$ values of $<0.001$ and 0.004 for HPV and HMTV, respectively (Table S2).

\section{Agreement of Viral Detection Between Fresh Tissues and Corresponding WBCs of $40 \mathrm{BC}$ Women}

The presence of HPV, EBV, and HMTV DNAs in fresh tissue alone, WBCs alone, or in both fresh tissues and WBCs, were analyzed to investigate the agreement between these two sample types (Table 4). HMTV was present in both fresh tissues and their corresponding WBCs of $21(52.5 \%)$ BC patients with a moderate statistical agreement between fresh tissue and WBCs (Kappa $=0.521, \mathrm{P}=0.001$ ). However, there was no statistical agreement between fresh tissue and corresponding WBCs for the presence of HPV or EBV.

\section{Prevalence of Single and Multiple Infections with HPV, EBV, and HMTV in Fresh Tissue and WBCs Samples of 40 BC Women}

According to qualitative PCR assay, patients were divided into two groups; patients positive for single viral DNA (HPV, EBV, or HMTV) and patients positive for 2 or 3 viral DNAs.

Table 3 HPV, EBV, and HMTV Frequency in FFPE Tissue and Fresh Tissue Samples of 80 BC Patients

\begin{tabular}{|l|c|c|c|}
\hline \multirow{3}{*}{ Virus Detected } & FFPE Tissue & Fresh Tissue & \multirow{2}{*}{ P value } \\
\cline { 2 - 3 } & $\mathbf{( N = 4 0 )}$ & $\mathbf{( N = 4 0 )}$ & \\
\cline { 2 - 3 } & $\mathbf{N}(\%)$ & $\mathbf{N}(\%)$ & \\
\hline HPV & $7(17.5 \%)$ & $20(50.0 \%)$ & 0.002 \\
EBV & $7(17.5 \%)$ & $23(57.5 \%)$ & $<0.00 \mathrm{I}$ \\
HMTV & $3(7.5 \%)$ & $28(70.0 \%)$ & $<0.00 \mathrm{I}$ \\
\hline
\end{tabular}

Notes: $\mathrm{P}$-value $>0.05$ not significant, $\mathrm{p}$-value $<0.05$ significant.

Abbreviations: $N$, number; FFPE, formalin fixed paraffin embedded.
Table 4 Agreement of Viral Detection Between Fresh Tissues and Corresponding WBCs of $40 \mathrm{BC}$ Women

\begin{tabular}{|l|c|c|c|}
\hline \multirow{2}{*}{ Type of Fresh Sample } & \multicolumn{3}{|c|}{ BC Patients N=40 } \\
& H (\%) \\
\cline { 2 - 4 } & HPV & EBV & HMTV \\
\hline Fresh tissue alone & $10(25.0 \%)$ & $19(47.5 \%)$ & $7(17.5 \%)$ \\
WBCs alone & $6(15.0 \%)$ & $0(0 \%)$ & $2(5.0 \%)$ \\
Both fresh tissue and WBCs & $10(25.0 \%)$ & $4(10.0 \%)$ & $21(52.5 \%)$ \\
None & $14(35.0 \%)$ & $17(42.5 \%)$ & $10(25.0 \%)$ \\
Kappa* & 0.200 & 0.152 & 0.521 \\
P value & 0.197 & 0.070 & 0.001 \\
\hline
\end{tabular}

Notes: P-value $>0.05$ not significant, $\mathrm{p}$-value $<0.05$ significant. *Kappa is a test for agreement between two sample types where 0.4 or more means agreement.

Abbreviation: $\mathrm{N}$, number

Regarding fresh tissues, single viral DNA was detected in $5(12.5 \%)$ BC patients, while multiple infections were detected in 27 (67.5\%) of the same group of patients. Regarding WBCs, single viral DNA was detected in $13(32.5 \%)$ BC patients, while multiple infections were detected in $14(35 \%)$ of the same group of patients.

The most frequent multiple infections present in the fresh tissues of BC patients were HPV/EBV/HMTV together found in $12(30 \%)$ out of 40 patients, followed by EBV/HMTV together in $7(17.5 \%)$ patients. Moreover, HPV/HMTV DNAs together were present in $4(10 \%)$ patients and HPV/EBV in $4(10 \%)$ patients. HMTV DNA was the only virus present alone in 5 $(12.5 \%)$ BC fresh tissues, and no HPV or EBV existed alone in any of the fresh tissue samples, as shown in Figure 1.

Regarding the presence of multiple viruses in WBCs of BC patients, HPV/EBV/HMTV DNAs together were found in only $2 / 40(5 \%)$. The most frequent viruses that were present in co-infection, were HPV/HMTV $(n=10$, $25 \%)$ followed by EBV/HMTV $(n=1,2.5 \%)$ and EBV/ HPV $(n=1,2.5 \%)$. HMTV was the predominating single virus $(\mathrm{n}=10,25 \%)$ and then HPV $(\mathrm{n}=3,7.5 \%)$. No EBV existed alone in any of the WBCs of studied BC patients, as shown in Figure 2.

\section{Specificity of HPV, EBV, and HMTV Primer Sequences Used for Qualitative PCR Assay}

Such assays were found to be highly specific for the HPV L1 region, EBV Bam H1 W region, and HMTV env sequence as none of the other tested viruses was amplified. 


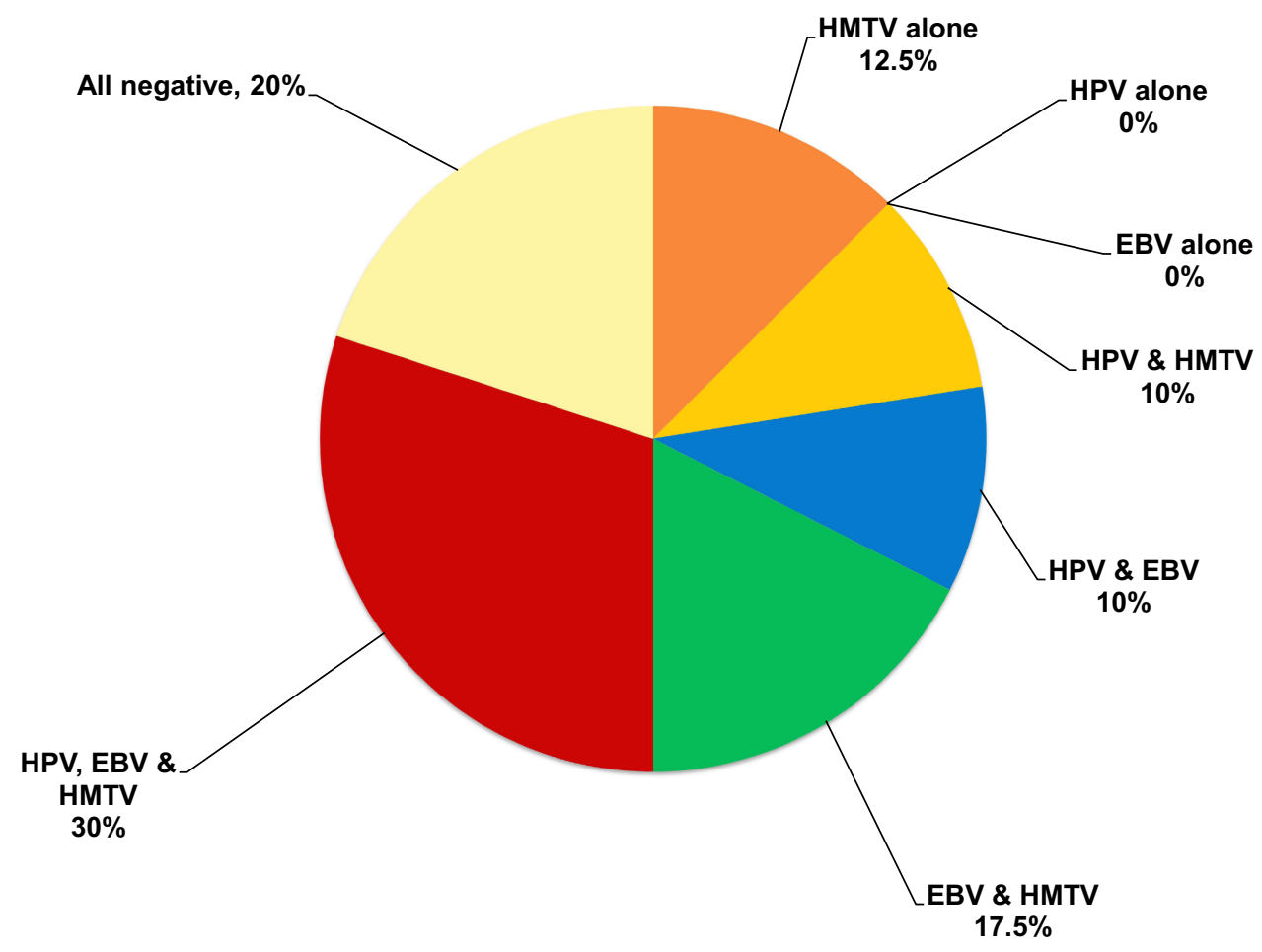

Figure I Detection of single and multiple HPV, EBV and HMTV infection among $40 \mathrm{BC}$ fresh tissue samples. HPV/EBV/HMTV together found in $30 \%$, followed by EBVI HMTV in $17.5 \%$, HPV/HMTV in 10\%, and HPV/EBV in 10\%. HMTV DNA was the only virus present alone in $12.5 \%$ of BC fresh tissues.

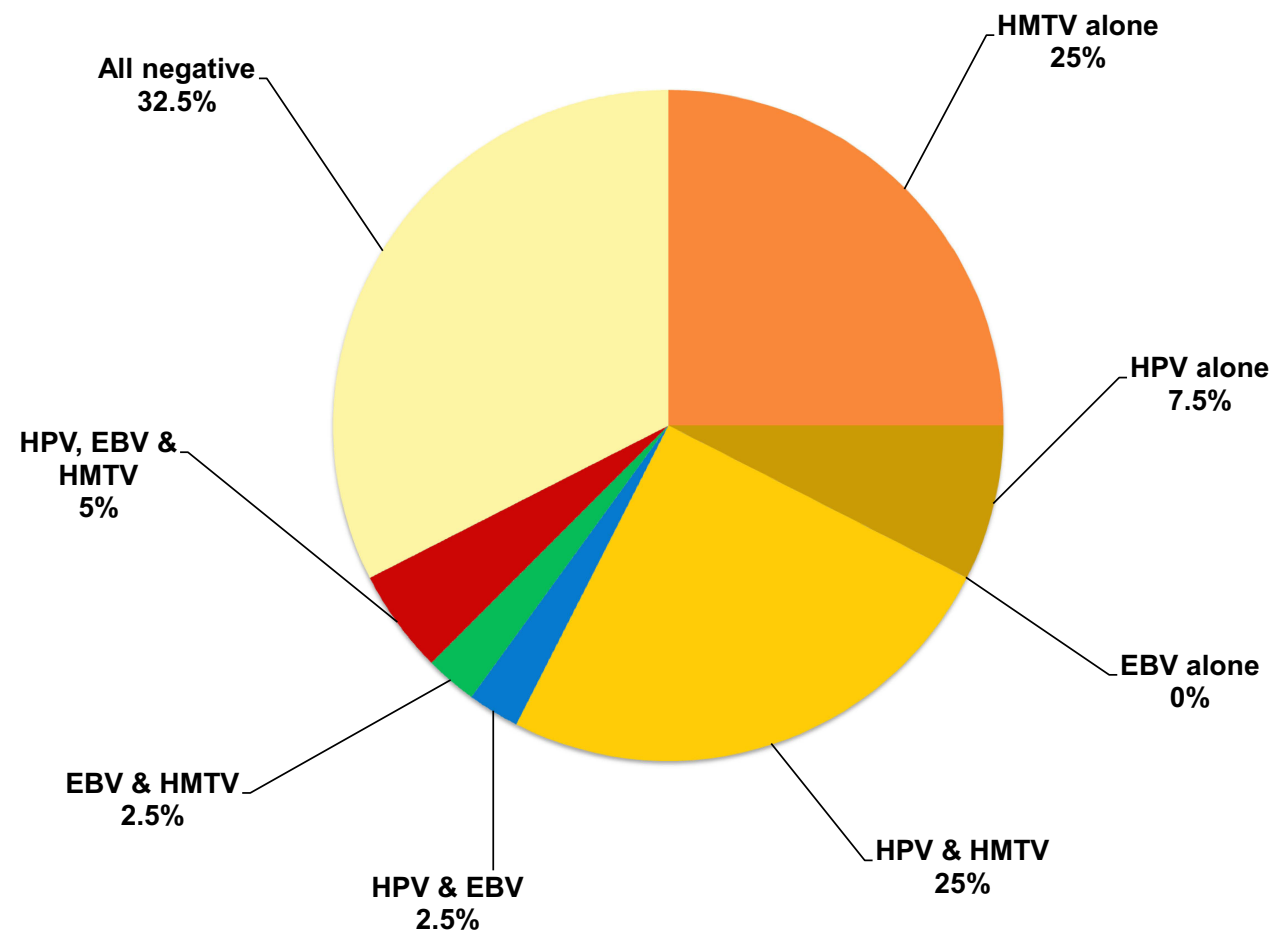

Figure 2 Detection of single and multiple HPV, EBV and HMTV infection among $40 \mathrm{BC}$ WBCs samples. HPV/EBV/HMTV DNAs together were found in only $5 \%$. The most frequent viruses present in co-infection were HPV/HMTV in $25 \%$ followed by EBV/HMTV in $2.5 \%$ and EBV/HPV in $2.5 \%$. HMTV was the predominating single virus present in $25 \%$ followed by HPV in $7.5 \%$. 


\section{Relations Between Presence of Viral DNAs and Some Clinico-Pathological Parameters of $40 \mathrm{BC}$ Patients with Blood Samples}

The statistical analysis showed a significant association between the high prevalence of EBV and HMTV DNAs among BC patients aged ( $\leq 45$ years), $\mathrm{P}=0.015$ and 0.001 , respectively. Moreover, there was a significant association between the absence of Her2-neu receptor expression and the presence of HMTV DNA $(\mathrm{P}=0.018)$, as presented in Table 5. Also, the presence of multiple infections was statistically associated with younger age ( $\leq 45$ years) of $\mathrm{BC}$ patients $(\mathrm{P}=0.014)$, as presented in Table 6 .

\section{HPV, EBV, and HMTV DNAs Viral Loads} HPV, EBV, and HMTV DNA viral loads were detected by quantitative real-time PCR in fresh tissue samples obtained from $\mathrm{BC}$ patients that were positive by qualitative PCR assay. HPV median load was 4800 copies $/ \mu \mathrm{L}$ ranged

Table 5 Relation Between Presence of HPV, EBV or HMTV Qualitative PCR and Clinico-Pathological Findings of 40 BC Patients

\begin{tabular}{|c|c|c|c|c|c|c|c|c|c|c|}
\hline \multirow{4}{*}{\multicolumn{2}{|c|}{ Factor (\% Within Factor Group) }} & \multicolumn{9}{|c|}{ Breast Cancer Patients $\mathrm{N}=\mathbf{4 0}$} \\
\hline & & \multicolumn{3}{|c|}{ HPV } & \multicolumn{3}{|c|}{ EBV } & \multicolumn{3}{|c|}{ HMTV } \\
\hline & & \multirow{2}{*}{$\begin{array}{c}\text { Positive } \\
\begin{array}{l}\text { N=20 } \\
(50 \%)\end{array}\end{array}$} & \multirow{2}{*}{$\begin{array}{c}\text { Negative } \\
\begin{array}{c}\mathrm{N}=20 \\
(50 \%)\end{array}\end{array}$} & \multirow[t]{2}{*}{$P$ value } & \multirow{2}{*}{$\begin{array}{c}\text { Positive } \\
\mathrm{N}=23 \\
(57.5 \%)\end{array}$} & \multirow{2}{*}{$\begin{array}{c}\text { Negative } \\
\begin{array}{c}N=17 \\
(42.5 \%)\end{array}\end{array}$} & \multirow[t]{2}{*}{$P$ value } & \multirow{2}{*}{$\begin{array}{c}\text { Positive } \\
\begin{array}{c}\text { N=28 } \\
(70.0 \%)\end{array}\end{array}$} & \multirow{2}{*}{$\begin{array}{c}\text { Negative } \\
\begin{array}{l}\mathrm{N}=12 \\
(30 \%)\end{array}\end{array}$} & \multirow[t]{2}{*}{$P$ value } \\
\hline & & & & & & & & & & \\
\hline \multirow{3}{*}{\multicolumn{2}{|c|}{$\begin{array}{l}\text { Age (years) } \\
\quad \begin{array}{l}\leq 45(\mathrm{n}=23) \\
>45(\mathrm{n}=17)\end{array}\end{array}$}} & & & & & & & & & \\
\hline & & $13(56.5 \%)$ & $10(43.5 \%)$ & 0.337 & $17(73.9 \%)$ & $6(26.1 \%)$ & 0.015 & $21(91.3 \%)$ & $2(8.7 \%)$ & 0.001 \\
\hline & & $7(41.2 \%)$ & $10(58.8 \%)$ & & $6(35.3 \%)$ & II(64.7\%) & & $7(41.2 \%)$ & $10(58.8 \%)$ & \\
\hline \multirow{2}{*}{\multicolumn{2}{|c|}{ BC Family history }} & & & & & & & & & \\
\hline & & $12(50 \%)$ & 12 (50\%) & 1.000 & $13(54.2 \%)$ & II(45.8\%) & 0.601 & 14 (58.3\%) & $10(41.7 \%)$ & 0.079 \\
\hline \multicolumn{2}{|c|}{$\begin{array}{l}\text { Namilial }(n=24) \\
\text { Non-familial }(n=16)\end{array}$} & $8(50 \%)$ & $8(50 \%)$ & & $10(62.5 \%)$ & $6(37.5 \%)$ & & 14 (87.5\%) & $2(12.5 \%)$ & \\
\hline \multicolumn{2}{|l|}{ Pathology } & & & & & & & & & \\
\hline \multirow{2}{*}{\multicolumn{2}{|c|}{$\begin{array}{l}\text { IDC }(n=36) \\
\text { ILC }(n=4)\end{array}$}} & $16(44.4 \%)$ & $20(55.6 \%)$ & 0.106 & $20(55.6 \%)$ & $16(44.4 \%)$ & 0.624 & $24(66.7 \%)$ & $12(33.3 \%)$ & 0.297 \\
\hline & & $4(100 \%)$ & $0(0 \%)$ & & $3(75 \%)$ & I (25\%) & & $4(100 \%)$ & $0(0 \%)$ & \\
\hline \multicolumn{2}{|c|}{ Tumor grade } & & & & & & & & & \\
\hline \multirow{2}{*}{\multicolumn{2}{|c|}{$\begin{array}{l}\text { Grade I }(n=1) \\
\text { Grade II }(n=36)\end{array}$}} & I (100\%) & $0(0 \%)$ & $*$ & $\mathrm{I}(100.0 \%)$ & $0(0 \%)$ & $*$ & $\mathrm{I}(100.0 \%)$ & $0(0 \%)$ & $*$ \\
\hline & & $16(44.4 \%)$ & $20(55.6 \%)$ & & 19 (52.8\%) & $17(47.2 \%)$ & & 24 (66.7\%) & $12(33.3 \%)$ & \\
\hline \multicolumn{2}{|c|}{ Grade III $(n=3)$} & $3(100 \%)$ & $0(0 \%)$ & & $3(100 \%)$ & $0(0 \%)$ & & $3(100.0 \%)$ & $0(0 \%)$ & \\
\hline \multicolumn{2}{|l|}{ Tumor size } & & & & & & & & & \\
\hline \multirow{2}{*}{\multicolumn{2}{|c|}{$\begin{array}{l}\leq 2.5 \mathrm{~cm}(\mathrm{n}=21) \\
>2.5 \mathrm{~cm}(\mathrm{n}=19)\end{array}$}} & 9 (42.9\%) & $12(57.1 \%)$ & 0.342 & $10(47.6 \%)$ & II(52.4\%) & 0.184 & 14 (66.7\%) & 7 (33.3\%) & 0.629 \\
\hline & & II (57.9\%) & $8(42.1 \%)$ & & $13(68.4 \%)$ & $6(31.6 \%)$ & & 14 (73.7\%) & $5(26.3 \%)$ & \\
\hline \multirow{2}{*}{\multicolumn{2}{|c|}{ Lymph nodes }} & & & & & & & & & \\
\hline & & $8(42.1 \%)$ & II(57.9\%) & 0.342 & 10 (52.6\%) & 9 (47.4\%) & 0.554 & 16 (84.2\%) & $3(15.8 \%)$ & 0.062 \\
\hline \multicolumn{2}{|c|}{$\begin{array}{l}\text { Positive }(n=19) \\
\text { Negative }(n=21)\end{array}$} & $12(57.1 \%)$ & 9 (42.9\%) & & 13 (61.9\%) & $8(38.1 \%)$ & & 12 (57.1\%) & $9(42.9 \%)$ & \\
\hline \multirow[t]{6}{*}{$\begin{array}{l}\text { Hormonal } \\
\text { receptors }\end{array}$} & $\begin{array}{c}\text { ER } \\
\text { Positive }(n=35)\end{array}$ & $16(45.7 \%)$ & $19(54.3 \%)$ & 0.342 & 20 (57.1\%) & $15(42.9 \%)$ & 1.000 & 25 (7I.4\%) & $10(28.6 \%)$ & 0.627 \\
\hline & Negative $(n=5)$ & $4(80 \%)$ & I (20\%) & & $3(60 \%)$ & $2(40 \%)$ & & $3(60 \%)$ & $2(40 \%)$ & \\
\hline & $\begin{array}{c}\text { PR } \\
\text { Positive }(n=35)\end{array}$ & $16(45.7 \%)$ & $19(54.3 \%)$ & 0.342 & 18 (51.4\%) & $17(48.6 \%)$ & 0.061 & $24(68.6 \%)$ & II(3I.4\%) & 1.000 \\
\hline & Negative $(n=5)$ & $4(80 \%)$ & I (20\%) & & $5(100 \%)$ & $0(0 \%)$ & & $4(80 \%)$ & I (20\%) & \\
\hline & $\begin{array}{c}\text { Her2-neu } \\
\text { Positive }(n=22)\end{array}$ & II (50\%) & II (50\%) & 1.000 & $12(54.5 \%)$ & $10(45.5 \%)$ & 0.676 & $12(54.5 \%)$ & $10(45.5 \%)$ & 0.018 \\
\hline & $\begin{array}{c}\text { Negative } \\
(n=18)\end{array}$ & $9(50 \%)$ & $9(50 \%)$ & & 11 (61.1\%) & 7 (38.9\%) & & 16 (88.9\%) & 2 (11.1\%) & \\
\hline
\end{tabular}

Notes: P-value $>0.05$ not significant, $\mathrm{p}$-value $<0.05$ significant. *No $\mathrm{p}$-value because of small number of cases within subgroups.

Abbreviations: N, number; IDC, invasive ductal carcinoma; ILC, invasive lobular carcinoma; Cm, centimeter; ER, estrogen receptors; PR, progesterone receptors; HER2, human epidermal growth factor receptor 2. 
Table 6 Relation Between Co-Existence of Viruses and Clinico-Pathological Findings of 40 BC Patients

\begin{tabular}{|c|c|c|c|c|c|}
\hline \multirow{3}{*}{\multicolumn{2}{|c|}{ Factor (\% Within Factor Group) }} & \multicolumn{4}{|c|}{ Breast Cancer Patients $\mathbf{N}=\mathbf{4 0}$} \\
\hline & & \multirow{2}{*}{$\begin{array}{c}\text { Single Virus (HPV, EBV or } \\
\text { HMTV) } \\
\mathrm{N}=5(12.5 \%)\end{array}$} & \multirow{2}{*}{$\begin{array}{c}\text { Multiple Viruses (Two or Three } \\
\text { Viruses) } \\
\mathrm{N}=27(67.5 \%)\end{array}$} & \multirow{2}{*}{$\begin{array}{c}\text { All } \\
\text { Negative }\end{array}$} & \multirow[t]{2}{*}{$P$ value } \\
\hline & & & & & \\
\hline \multirow{2}{*}{\multicolumn{2}{|c|}{$\begin{array}{l}\text { Age (years) } \\
\leq 45(n=23)\end{array}$}} & & & & 0.014 \\
\hline & & $3(13 \%)$ & $19(82.6 \%)$ & I (4.3\%) & \\
\hline \multicolumn{2}{|c|}{$>45(n=17)$} & $2(11.8 \%)$ & $8(47.1 \%)$ & 7 (4I.2\%) & \\
\hline \multirow{3}{*}{\multicolumn{2}{|c|}{$\begin{array}{l}\text { Pathology } \\
\qquad \text { IDC }(n=36) \\
\text { ILC }(n=4)\end{array}$}} & & & & 0.744 \\
\hline & & $5(13.9 \%)$ & $23(63.9 \%)$ & $8(22.2 \%)$ & \\
\hline & & $0(0 \%)$ & $4(100 \%)$ & $0(0 \%)$ & \\
\hline \multicolumn{2}{|c|}{ BC Family history } & & & & 0.067 \\
\hline \multicolumn{2}{|c|}{ Familial $(n=24)$} & I (4.2\%) & $16(66.7 \%)$ & 7 (29.2\%) & \\
\hline \multicolumn{2}{|c|}{ Non-familial $(n=16)$} & $4(25 \%)$ & II (68.8\%) & I (6.3\%) & \\
\hline \multirow{3}{*}{\multicolumn{2}{|c|}{$\begin{array}{l}\text { Tumor size } \\
\qquad 2.5 \mathrm{~cm}(\mathrm{n}=21) \\
>2.5 \mathrm{~cm}(\mathrm{n}=19)\end{array}$}} & & & & 0.360 \\
\hline & & $3(14.3 \%)$ & $12(57.1 \%)$ & $6(28.6 \%)$ & \\
\hline & & $2(10.5 \%)$ & 15 (78.9\%) & $2(10.5 \%)$ & \\
\hline \multicolumn{2}{|c|}{ Tumor grade } & & & & * \\
\hline \multicolumn{2}{|c|}{ Grade I $(n=I)$} & $0(0 \%)$ & I (I00\%) & $0(0 \%)$ & \\
\hline \multicolumn{2}{|c|}{ Grade II $(n=36)$} & 5 (13.9\%) & $23(63.9 \%)$ & $8(22.2 \%)$ & \\
\hline \multicolumn{2}{|c|}{ Grade III $(n=3)$} & $0(0 \%)$ & $3(100 \%)$ & $0(0 \%)$ & \\
\hline \multirow{3}{*}{\multicolumn{2}{|c|}{$\begin{array}{l}\text { Lymph nodes } \\
\text { Positive }(n=19) \\
\text { Negative }(n=21)\end{array}$}} & & & & 0.187 \\
\hline & & $4(21.1 \%)$ & I3 (68.4\%) & $2(10.5 \%)$ & \\
\hline & & I (4.8\%) & $14(66.7 \%)$ & $6(28.6 \%)$ & \\
\hline \multirow{9}{*}{$\begin{array}{l}\text { Hormonal } \\
\text { receptors }\end{array}$} & ER & & & & 1.000 \\
\hline & Positive $(n=35)$ & $5(\mid 4.3 \%)$ & $23(65.7 \%)$ & $7(20 \%)$ & \\
\hline & Negative $(n=5)$ & $0(0 \%)$ & $4(80 \%)$ & I (20\%) & \\
\hline & PR & & & & 0.351 \\
\hline & Positive $(n=35)$ & $5(\mid 4.3 \%)$ & 22 (62.9\%) & $8(22.9 \%)$ & \\
\hline & Negative $(n=5)$ & $0(0 \%)$ & $5(100 \%)$ & $0(0 \%)$ & \\
\hline & Her2-neu & & & & 0.501 \\
\hline & Positive $(n=22)$ & $2(9.1 \%)$ & 14 (63.6\%) & $6(27.3 \%)$ & \\
\hline & Negative $(n=18)$ & $3(16.7 \%)$ & I3 (72.2\%) & 2 (II.I\%) & \\
\hline
\end{tabular}

Notes: P-value $>0.05$ not significant, $\mathrm{p}$-value $<0.05$ significant. *No $\mathrm{p}$-value because of small number of cases within subgroups.

Abbreviations: N, number; IDC, invasive ductal carcinoma; ILC, invasive lobular carcinoma; Cm, centimeter; ER, estrogen receptors; PR, progesterone receptors; HER2, human epidermal growth factor receptor 2 .

from $3.3 \times 10^{2}$ to $7 \times 10^{4}$ copies $/ \mu \mathrm{L}$. EBV median load was $6.3 \times 10^{3}$ copies/ $\mu \mathrm{L}$ ranged from 49.8 to $120 \times 10^{4}$ copies/ $\mu \mathrm{L}$. In addition, HMTV median load was 97 copies $/ \mu \mathrm{L}$ ranged from $1.2 \times 10^{1}$ to $1.3 \times 10^{3}$ copies $/ \mu \mathrm{L}$.

There was no significant association between EBV or HMTV viral load and any of clinico-pathological findings. However, HPV DNA viral load was significantly higher in patients $\leq 45$ years (median: $1.2 \times 10^{4}$ copies $/ \mu \mathrm{L}$, range: $1.7 \times 10^{3}$ to $7 \times 10^{4}$ copies $/ \mu \mathrm{L}$ ) than older patients (median: $4.8 \times 10^{2}$, range: $3.3 \times 10^{2}$ to $3.3 \times 10^{3}$ copies $/ \mu \mathrm{L}, \mathrm{p}<0.001$ ).

\section{Discussion}

It was reported that some oncogenic viruses play a major role in the development of $\mathrm{BC}$, and also their presence may aggravate disease outcomes. ${ }^{7} \mathrm{HPV}, \mathrm{EBV}$, and HMTV were the most investigated in many countries. ${ }^{9,12,16,19,33}$ However, very limited studies investigated the presence of EBV with HPV and HMTV as single or multiple viruses and their association with clinico-pathological characteristics of $\mathrm{BC}$ disease. 
The current study showed that HPV DNA was detected in $17.5 \%$ of FFPE tissue specimens, $50 \%$ of fresh $\mathrm{BC}$ tissues, and $40 \%$ of WBCs. This was in agreement with a previous report on Iranian BC women showing HPV DNA in $25.9 \%$ FFPE tissue specimen using PCR targeting the HPV L1 region. ${ }^{35}$ Another study reported the presence of HPV DNA in fresh tissue of $48.6 \%$ of Iranian BC patients. ${ }^{9}$ However, a report from Egypt demonstrated a higher percentage of HPV-16 in fresh tissues of $75.8 \%$ of non-inflammatory $\mathrm{BC}$ patients and $65.9 \%$ of inflammatory $\mathrm{BC}$ cases using PCR targeting HPV L1 region. ${ }^{19}$ This difference between reports may be attributed to the difference in the pathology of the disease and the presence of a specific type of HPV. ${ }^{36}$

In contrast, other reports showed a negative result for the presence of HPV DNA in FFPE BC tissues of 300 Iranian BC women, ${ }^{37} 81$ Swiss BC females, ${ }^{38}$ and 50 French BC females. ${ }^{39}$ Another report from Egypt demonstrated the presence of HPV DNA in $16.7 \%$ of fresh BC tissues. ${ }^{31}$ Other studies demonstrated the absence of HPV DNA in fresh tissues. ${ }^{40}$ The difference in result may be due to low viral load, ${ }^{41,42}$ possible inter-laboratory inconsistency in collecting and handling samples ${ }^{38}$ and storage of specimens. ${ }^{43}$

EBV DNA was detected in $17.5 \%$ of FFPE tissues, $57.5 \%$ of fresh tissues, and $10 \%$ of WBCs. A study from Egypt reported the detection of EBV DNA using PCR targeting EBV nuclear antigen-1 (EBNA-1) gene in 20\% of FFPE BC tissues. ${ }^{14}$ Moreover, it was detected in fresh samples of $53.3 \%$ of Sudanese BC patients using methylation-based PCR targeting Latent membrane protein-1 (LMP-1). ${ }^{44}$ In agreement, a study performed by Marro et al $(2014)^{45}$ observed the presence of EBV DNA in $25.8 \%$ of FFPE BC tissues, but they reported higher result in peripheral blood mononuclear cell (PBMC) samples of $47 \%$ BC patients using quantitative real-time PCR of BXLF1 gene. In addition, a study from China reported EBV DNA in $24.4 \%$ of PBMCs of BC patients using Realtime PCR targeting BamH1-K. ${ }^{46}$

Higher result of EBV DNA detection was also reported in $45 \%$ of Egyptian and $51.85 \%$ of Syrian FFPE BC tissues using PCR targeting EBNA-1 and LMP-1. ${ }^{47,48}$ Such discrepancy may be due to population characteristics differences, ${ }^{49}$ decreased socioeconomic status of the infected persons, ${ }^{50}$ difference in EBV derived nucleic acid target genes investigated ${ }^{51}$ and PCR false-positive result caused by amplicon contamination ${ }^{52}$ or presence of EBV in lymphocytes. ${ }^{53}$
In contrast, a low percentage of EBV DNA was also found in $5.12 \%$ of FFPE tissues of Iranian women. ${ }^{54}$ However, EBV DNA was not detected in FFPE tissues of Iranian women using PCR targeting the Bam HI-H rightward open reading frame 1 (BHRF1) region. ${ }^{55}$ Moreover, EBV DNA was detected using PCR in $20 \%$ of fresh tissues of Egyptian BC patients, ${ }^{56} 4.7 \%$ of Mexican $\mathrm{BC}$ patients, ${ }^{57}$ and $31 \%$ of Argentinian BC patients. ${ }^{58}$ These lower detection rates could be due to differences in storage methods of samples. ${ }^{59}$ At the same time, the false-negative result may be caused by 1) the presence of viral targets at levels that extend the sensitivity threshold of the assay, ${ }^{13,60}$ 2) removal of Epstein-Barr virus-encoded small RNAs (EBER) coding sequences from the EBV genome, ${ }^{50} 3$ ) alterations related to the integration of virus DNA into the host chromosomal DNA, ${ }^{61} 4$ ) hit-andrun mechanism, ${ }^{62}$ ) heterogeneous distribution of EBV genomes in morphologically matched tumor cells. ${ }^{59}$

HMTV DNA was detected in $7.5 \%$ of FFPE tissues, $70 \%$ of fresh tissues, and $57.5 \%$ of WBCs of BC patients. In Saudi Arabia, Dossary and Associates $(2018)^{11}$ found viral DNA in $7.7 \%$ of FFPE BC tissue samples. Glenn et al (2012) ${ }^{16}$ reported its presence in $78 \%$ of fresh DNA extracts from Australian BC women. This was in contrast with previous reports where HMTV DNA was present in $36 \%$ of FFPE tissues from BC Egyptians, ${ }^{63} 57.89 \%$ from BC Iraqis, ${ }^{34} \% 32.2$ from BC Iranians, ${ }^{64}$ and $37.3 \%$ from BC Australians. ${ }^{65}$ Even the picture was different when fresh tissues were used, where the lower result was also reported in many countries, including $13.9 \%$ in Tunisia, ${ }^{66} 37 \%$ in New York, ${ }^{67}$ and $0 \%$ in Mexico. ${ }^{57}$ In addition, MMTV-Long terminal repeat (LTR) gene sequence was detected in peripheral blood samples of $38 \%$ of $\mathrm{BC}$ patients from Pakistan. ${ }^{12}$ Moreover, 300 WBCs samples of Iranian BC women were negative for MMTV. ${ }^{68}$ These lower rates could be due to the probable low viral load in BCs, the extraction methods, and the sensitivity of PCR. ${ }^{64,65,69,70}$ Also, it was reported that mutations or rearrangements of viral sequences make their detection difficult. ${ }^{66}$ Moreover, the high frequency of HMTV DNA in fresh tissue obtained in this study compared to studies from different countries may be due to a high level of contact with domestic animals. ${ }^{71}$

Our result showed that the presence of viral DNAs in FFPE tissues was significantly lower than that in fresh tissue samples, possibly due to DNA degradation during paraffin fixation. ${ }^{72}$ Therefore, we focused on the result obtained from fresh tissues for virological and clinical 
analysis. Interestingly, our result demonstrated a statistical agreement between fresh tissues and WBCs for the detection of HMTV in BC samples. This indicates a clinical relevance of WBCs as a suitable specimen instead of fresh tissue for HMTV detection in BC patients hence avoiding invasive procedures.

HPV and EBV DNAs were not detected in WBCs of healthy controls. This was in contrast to other studies which reported various percentages based on genetic, environmental, and geographical variations. ${ }^{36,46,73-75}$ However, HMTV DNA was detected in $23 \%$ of WBCs of our controls, possibly due to contact with their relative $\mathrm{BC}$ patients or exposure to the virus through vectors and environmental conditions.

The result showed that the presence of multiple viral infections was more frequent $(67.5 \%)$ than the presence of a single infection (12.5\%). Multiple viral infections were reported at only $10 \%$ in a previous study on 40 fresh tissues with primary breast carcinoma. ${ }^{20}$ Whether multiple viral infections have a role in the outcome of the disease needs further investigations.

Upon investigating the correlation between single and multiple infections in fresh tissues and some clinicopathological parameters, we found that multiple viral infections were associated with the young age of BC women as reported previously ${ }^{16}$ that may be related to sex hormones. ${ }^{2}$ Such association needs to be further investigated. High HPV viral load was also associated with young age $(\leq 45 \mathrm{y})$. This may lead to lower expression of breast cancer gene 1 (BRCA1) gene expression and hence early development of $\mathrm{BC}$ as previously explained. ${ }^{76,77}$ Limitations to this study are the relatively small size of samples used. The biological activity of such viruses needs to be further investigated in a larger sample size by exploring the presence of viral transcripts and detection of infectious virions.

\section{Conclusion}

Up to our knowledge, this is the first report, in the Arab world, concerning the presence of HPV, EBV, and HMTV and their association with some clinico-pathological characteristics of BC disease. HPV and HMTV have been the most prevalent viruses among studied Egyptian women with BC. The three viruses together (HPV/EBV/HMTV) have existed in about one-third of fresh tissues of studied BC patients. Fresh tissues have been a more favorable specimen than FFPE to detect viral DNAs in BC patients. WBCs could be a more suitable specimen instead of fresh tissue for HMTV detection in BC patients to avoid invasive procedures. Detection of HPV DNA among young women ( $\leq 45$ years) might be a relevant prognostic marker for the clinical course of BC disease. Further analysis is needed to explore the environmental cause of oncogenic virus infections on a large number of $\mathrm{BC}$ patients and controls. In addition, additional analysis is required to investigate the inverse relation between HMTV and HER2 expression and the linkage of HMTV to HPV, EBV, and their biological activities and impact on the outcome of $\mathrm{BC}$ disease.

\section{Abbreviations}

BHRF1, BamHI-H rightward open reading frame 1; $\mathrm{BC}$, breast cancer; bp, base pair; BRCA1, breast cancer gene 1; $\mathrm{Cm}$, centimeter; E, early; EBER, EBV-encoded small RNA; EBNA, EBV nuclear antigen; EBV, EpsteinBarr virus; Env, envelope; ER, estrogen receptor; FFPE, formalin fixed and paraffin embedded; FG, femtogram; Her2, human epidermal growth factor receptor 2; HMTV, human mammary tumor virus; HPV, human papillomavirus; IDC, invasive ductal carcinoma; ILC, invasive lobular carcinoma; IRP, the institutional review board; L, late; LMP, latent membrane protein; MCF7, Michigan Cancer Foundation-7; MMTV-Ltr, Mouse mammary tumor virus long terminal repeat; N, number; NCI, National Cancer Institute; $\mathrm{Ng}$, nanogram; PBMC, peripheral blood mononuclear cell; PCR, polymerase chain reaction; PR, progesterone receptor; TAE, tris-acetate buffer; UV, ultraviolet; WBCs, white blood cells; $\mu \mathrm{g} / \mathrm{mL}$, microgram per milliliter; $\mu \mathrm{L}$, microliter; $\mu \mathrm{M}$, micromolar.

\section{Data Sharing Statement}

The datasets used and/or analyzed during the current study available from the corresponding author upon reasonable request.

\section{Ethics Approval and Informed Consent}

The study was conducted according to the guidelines of the Declaration of Helsinki, and the research has been approved by the National Cancer Institute-Cairo University, IRB. IRB number 201819039.3, Organization number IORG0003381.

\section{Informed Consent Statement}

Informed consent was obtained from all subjects involved in the study. 


\section{Funding}

This project was supported financially by the Science and Technology Development Fund (STDF), Egypt, [Grant No. 22944].

\section{Disclosure}

The authors declare that they have no conflicts of interest for this work.

\section{References}

1. Ferlay J, Ervik M, Lam F, et al. Egypt source: globocan 2020. Global Cancer Observatory; 2020. Available from: https://gco.iarc.fr/today/ data/factsheets/populations/818-egypt-fact-sheets.pdf. Accessed January 29, 2021.

2. Alibek K, Kakpenova A, Mussabekova A, Sypabekova M, Karatayeva N. Role of viruses in the development of breast cancer Infect Agent Cancer. 2013;8(1):1-6. doi:10.1186/1750-9378-8-32

3. Lawson JS, Salmons B, Glenn WK. Oncogenic viruses and breast cancer: mouse mammary tumor virus (MMTV), bovine leukemia virus (BLV), human papilloma virus (HPV), and Epstein-Barr virus (EBV). Front Oncol. 2018;8(1):1-18. doi:10.3389/fonc.2018.00001

4. Simões PW, Medeiros LR, Pires PDS, et al. Prevalence of human papillomavirus in breast cancer: a systematic review. Int $J$ Gynecol Cancer. 2012;22(3):343-347. doi:10.1097/IGC.0b013e31823c712e

5. San TH, Fujisawa M, Fushimi S, et al. Low prevalence of human mammary tumor virus (HMTV) in breast cancer patients from Myanmar. Infect Agent Cancer. 2017;12(1):1-7. doi:10.1186/ s13027-017-0130-0

6. Farahmand M, Monavari SH, Shoja Z, Ghaffari H, Tavakoli M, Tavakoli A. Epstein Barr virus and risk of breast cancer: a systematic review and meta-analysis. Futur Oncol. 2019;15 (24):2873-2885. doi:10.2217/fon-2019-0232

7. Naushad W, Surriya O, Sadia H. Prevalence of EBV, HPV and MMTV in Pakistani breast cancer patients: a possible etiological role of viruses in breast cancer. Infect Genet Evol. 2017;54:230-237. doi:10.1016/j.meegid.2017.07.010

8. Yasmeen A, Bismar TA, Kandouz M, Foulkes WD, Desprez PY, Al Moustafa AE. E6/E7 of HPV type 16 promotes cell invasion and metastasisof human breast cancer cells. Cell Cycle. 2007;6 (16):2038-2042. doi:10.4161/cc.6.16.4555

9. Khodabandehlou N, Mostafaei S, Etemadi A, et al. Human papilloma virus and breast cancer: the role of inflammation and viral expressed proteins. BMC Cancer. 2019;19(1):1-11. doi:10.1186/s12885-0195286-0

10. Girianelli VR, Thuler LCS, Silva GAE. Prevalence of HPV infection among women covered by the Family Health Program in the Baixada Fluminense, Rio de Janeiro, Braz. Rev Bras Ginecol e Obs. 2010;32 (1):39-46. doi:10.1590/s0100-72032010000100007

11. Dossary RA, Alkharsah KR, Kussaibi H. Prevalence of Mouse Mammary Tumor Virus (MMTV)-like sequences in human breas cancer tissues and adjacent normal breast tissues in Saudi Arabia. BMC Cancer. 2018;18(1):1-10. doi:10.1186/s12885-018-4074-6

12. Naushad W, Ayub S, Sadia H. Significant correlation of MMTV (Mouse mammary tumor virus) LTR gene with hormone receptor status in peripheral blood samples of breast cancer patients from North Pakistan. Int J Biosci. 2017;6655:399-405. doi:10.12692/ijb/ 10.3.399-405

13. Bonnet M, Guinebretiere JM, Kremmer E, et al. Detection of Epstein-Barr virus in invasive breast cancers. J Natl Cancer Inst. 1999;91(16):1376-1381. doi:10.1093/jnci/91.16.1376
14. Fawzy S, Sallam M, Mohammad N. Detection of Epstein - Barr virus in breast carcinoma in Egyptian women. Clin Biochem. 2008;41:486-492. doi:10.1016/j.clinbiochem.2007.12.017

15. Hassab El-Naby NED, Hameda HM, Asmaa MG, Ahmed ESM. Epstein-Barr virus infection and breast invasive ductal carcinoma in Egyptian women: a single center experience. J Egypt Natl Canc Inst. 2017;29(2):77-82. doi:10.1016/j.jnci.2017.02.002

16. Glenn W, Heng B, Delprado W, Iacopetta B, Whitaker NJ, Lawson JS. Epstein-Barr virus, human papillomavirus and mouse mammary tumour virus as multiple viruses in breast cancer. PLoS One. 2012;7(11):e48788. doi:10.1371/journal.pone.0048788

17. Al Moustafa A, Al-Antary N, Al-Antary N, et al. Co-prevalence of Epstein-Barr virus and high-risk human papillomaviruses in Syrian women with breast cancer. Hum Vaccin Immunother. 2016;12 (7):1936-1939. doi:10.1080/21645515.2016.1139255

18. Ahmed RA, Yussif SM. Immunohistochemical detection of human cytomegalovirus, Epstein-Barr virus and human papillomavirus in invasive breast carcinoma in Egyptian women: a tissue microarray study. J Solid Tumors. 2016;6(2):8-16. doi:10.5430/jst.v6n2p8

19. El-shinawi M, Mohamed HT, Abdel-fattah HH, Mohamed MM. Inflammatory and non-inflammatory breast cancer: a potential role for detection of multiple viral DNAs in disease progression. Ann Surg Oncol. 2016;23(2):494-502. doi:10.1245/s10434-015-4888-2

20. Gad Al Karim AS, Sharaf AEMM, El-Fadeel MA, Al-Shinawi MS, El-Mahdy H. Molecular characterization of viruses involvement in breast cancer patients. Cancer Biol. 2014;4(3):22-34. doi:10.1080/ 14768320500230185

21. Lakhani SR, Ellis IO, Schnitt SJ, Tan PH, Van de Vijvr MJ. WHO Classification of Tumors of the Breast. Pathology and Genetics of Tumors of Breast and Female Genital Organs. 4th ed. IARC Press; 2012.

22. Easton DF. Familial risks of breast cancer. Breast Cancer Res. 2002;4 (5):179-181. doi:10.1186/bcr448

23. Van Der Bij W, Torensma R, Van Son WJ, et al. Rapid immunodiagnosis of active cytomegalovirus infection by monoclonal antibody staining of blood leucocytes. J Med Virol. 1988;25(2):179-188. doi:10.1002/jmv.1890250208

24. Loutfy SA, Fawzy M, El-Wakil M, Moneer MM. Presence of human herpes virus 6 (HHV6) in pediatric lymphomas: impact on clinical course and association with cytomegalovirus infection. Virol $\mathrm{J}$. 2010;7(1):287. doi:10.1186/1743-422X-7-287

25. Manos MM, Ting Y, Wright DK, Lewis AJ, Broker TR, Wolinsky SM. Use of polymerase chain reaction amplification for the detection of genital human papillomaviruses. In: Cancer Cells. 7th ed. Cold Spring Harbor Laboratory Press; 1989:214.

26. Hashimoto. Y, Nawata. Y, Kurasawa. K, et al. Investigation of EB VIRUS and cytomegalovirus in rapidly progressive interstetial pneumonitis in polymyositis/dermatomyositis by in situ hyberdization and polymerase chain reaction. Clin Immunol Immunol Pathol. 1995;77 (3):298-306. doi:10.1006/clin.1995.1156

27. Loutfy SA, Abo-shadi MA, Fawzy M, et al. Epstein-Barr virus and cytomegalovirus infections and their clinical relevance in Egyptian leukemic pediatric patients. Virol J. 2017;2:1-11. doi:10.1186/ s12985-017-0715-7

28. Wang Y, Holland JF, Bleiweiss IJ, et al. Detection of mammary tumor virus ENV gene-like sequences in human breast cancer. Cancer Res. 1995;55(22):5173-5179.

29. Islam S, Dasgupta H, Roychowdhury A, et al. Study of association and molecular analysis of human papillomavirus in breast cancer of Indian patients: clinical and prognostic implication. PLoS One. 2017;12(2):1-17. doi:10.1371/journal.pone.0172760

30. Fernandez-Cobo M, Melana SM, Holland JF, Pogo BGT. Transcription profile of a human breast cancer cell line expressing MMTV-like sequences. Infect Agent Cancer. 2006;1(1):1-5. doi:10.1186/1750-9378-1-7 
31. ElSheshtawy NM, Shakweer MM, EL-Ghamrini YM. Is HPV virus associated with human breast cancer? Time to re-examine the postulate. Egyptian Study. Ann Pathol Lab Med. 2017;4(1):A1-A9. doi:10.21276/apalm.2017.1143

32. Elashoff JD. nQuery Advisor. Version 7.0 User's Guide. V edition. Statistical Solutions Ltd.; 2007.

33. Habyarimana T, Attaleb M, Baptiste J, Youssef M, Mohammed B, Mzibri E. Detection of human papillomavirus DNA in tumors from Rwandese breast cancer patients. Breast Cancer. 2018;25 (2):127-133. doi:10.1007/s12282-018-0831-2

34. Alshammari AMA, Tarish HR, Aljanabi A. Detection of mouse mammary tumor virus-like sequence (MMTV- like sequence) in the breast cancer of Iraqi women samples by nested PCR. Kufa J Nurs Sci. 2014;4(2):34-143.

35. Sigaroodi A, Nadji SA, Naghshvar F, Nategh R, Emami H, Velayati AA. Human papillomavirus is associated with breast cancer in the north part of Iran. Sci World J. 2012;2012:8. doi:10.1100/2012/ 837191

36. Eslamifar A, Ramezani A, Azadmanesh K, Bidari-Zerehpoosh F, Banifazl M, Aghakhani. A. Assessment of the association between human papillomavirus infection and breast carcinoma. Iran J Pathol. 2015;10(1):41-46.

37. Bakhtiyrizadeh S, Hosseini SY, Yaghobi R, Sarvari J. Almost complete lack of human cytomegalovirus and human papillomaviruses genome in benign and malignant breast lesions in Shiraz, Southwest of Iran. Asian Pacific J Cancer Prev. 2017;18:3319-3324. doi:10.22034/APJCP.2017.18.12.3319

38. Lindel K, Forster A, Altermatt HJ, Greiner R, Gruber G. Breast cancer and human papillomavirus (HPV) infection: no evidence of a viral etiology in a group of Swiss women. Breast. 2007;16 (2):172-177. doi:10.1016/j.breast.2006.09.001

39. De Cremoux P, Thioux M, Lebigot I, Sigal-Zafrani B, Salmon R, Sastre-Garau X. No evidence of Human papillomavirus DNA sequences in invasive breast carcinoma. Breast Cancer Res Treat. 2008;109(1):55-58. doi:10.1007/s10549-007-9626-4

40. Hedau S, Kumar U, Hussain S, et al. Breast cancer and human papillomavirus infection: no evidence of HPV etiology of breast cancer in Indian women. BMC Cancer. 2011;11(1):27. doi:10.1186/ 1471-2407-11-27

41. Teo IA, Shaunak S. Polymerase chain reaction in situ: an appraisal of an emerging technique. Histochem J. 1995;27(9):647-659. doi:10.1007/BF00216678

42. Khan NA, Castillo A, Koriyama C, et al. Human papillomavirus detected in female breast carcinomas in Japan. $\mathrm{Br} J$ Cancer. 2008;99(3):408-414. doi:10.1038/sj.bjc.6604502

43. Chang P, Wang T, Yao Q, Wang L, Chen J. Absence of human papillomavirus in patients with breast cancer in north-west China. Med Oncol. 2012;29:521-525. doi:10.1007/s12032-011-9945-5

44. Yahia ZA, Adam AAM, Elgizouli M, et al. Epstein Barr virus: a prime candidate of breast cancer aetiology in Sudanese patients. Infect Agent Cancer. 2014;9(1):1-5. doi:10.1186/1750-9378-9-9

45. Marrão G, Habib M, Paiva A, et al. Epstein-Barr virus infection and clinical outcome in breast cancer patients correlate with immune cell TNF- $\alpha /$ IFN- $\gamma$ response. BMC Cancer. 2014;14(1):1-11. doi:10.1186/1471-2407-14-665

46. Zhang W, Wang M, Wei X, et al. Associations of Epstein-Barr virus DNA in PBMCs and the subtypes with breast cancer risk. $J$ Cancer. 2017;8(15):2944-2949. doi:10.7150/jca.20330

47. Zekri AN, Bahnassy AA, Mohamed WS, Hassan ZK. Epstein-Barr virus and breast cancer: epidemiological and molecular study on Egyptian and Iraqi women. J Egypt Natl Canc Inst. 2012;24 (3):123-131. doi:10.1016/j.jnci.2012.06.001

48. Aboulkassim T, Yasmeen A, Akil N, Batist G, Moustafa AA. Incidence of Epstein - barr virus in Syrian women with breast cancer: a tissue microarray study. Hum Vaccin Immunother. 2015;11 (4):951-955. doi:10.1080/21645515.2015.1009342
49. Wiencke JK. Impact of race/ethnicity on molecular pathways in human cancer. Nat Rev Cancer. 2004;4(1):79-84. doi:10.1038/ $\operatorname{nrc} 1257$

50. Glaser SL, Hsu JL, Gulley ML. Epstein-Barr virus and breast cancer: state of the evidence for viral carcinogenesis. Cancer Epidemiol Biomarkers Prev. 2004;13(5):688-697.

51. Yasui Y, Potter JD, Stanford JL, et al. Breast cancer risk and "delayed" primary Epstein-Barr virus infection. Cancer Epidemiol Biomarkers Prev. 2001;10(1):9-16.

52. Gulley ML. Molecular diagnosis of Epstein-Barr virus-related diseases. J Mol Diagn. 2001;3(1):1-10. doi:10.1016/S15251578(10)60642-3

53. Brink AA, Van Den Brule AJ, Van Diest P, Meijer CJ. Re: detection of Epstein-Barr virus in invasive breast cancers. J Natl Cancer Inst. 1992;84(9):655-656. doi:10.1093/jnci/92.8.655

54. Saeedi Z, Hadi F, Hejazi SH, Salahshournia Z. The relationship between EBV virus and breast cancer in Khuzestan Province of Iran. J Appl Biotechnol Rep. 2018;5(1):37-41. doi:10.29252/ jabr.01.01.07

55. Dowran R, Joharinia N, Safaei A, Bakhtiyarizadeh S, Soleimani AA. No detection of EBV, BKV and JCV in breast cancer tissue samples in Iran. BMC Res Notes. 2019;12(1):1-5. doi:10.1186/s13104-0194178-3

56. Sharaf HM, Gomaa MF. Molecular detection of Epstein-Barr virus in breast cancer. Egypt J Hosp Med. 2012;47(1):238-248. doi:10.21608/ ejhm.2012.16294

57. Morales-sa A, Martı JLE, Mantilla A, Leal YA, Torres J, Fuentespanana EM. No association between Epstein-Barr virus and mouse mammary tumor virus with breast cancer in Mexican Women. Sci Rep. 2013;3:2970. doi:10.1038/srep02970

58. Ribeiro-Silva A. Epstein-Barr virus in breast carcinoma in Argentina. Arch Pathol Lab Med. 2005;129(9):1088. doi:10.5858/2005-1291088-EVIBCI

59. Arbach H, Viglasky V, Lefeu F, et al. Epstein-Barr Virus (EBV) genome and expression in breast cancer tissue: effect of EBV infection of breast cancer cells on resistance to paclitaxel (Taxol). $J$ Virol. 2006;80(2):845-853. doi:10.1128/jvi.80.2.845-853.2006

60. Herrmann K, Niedobitek G. Lack of evidence for an association of Epstein-Barr virus infection with breast carcinoma. Breast Cancer Res. 2002;5(1):13-17. doi:10.1186/bcr561

61. Griffin BE. Epstein-Barr virus (EBV) and human disease: facts, opinions and problems. Rev Mutat Res. 2000;462(2-3):395-405. doi:10.1016/S1383-5742(00)00028-4

62. Labrecque LG, Barnes DM, Fentiman IS, Griffin BE. Epstein-Barr virus in epithelial cell tumors: a breast cancer study. Cancer Res. 1995;55(1):39-45.

63. Hafez. MM, Hassan. ZK, Kamel MM, Rouby MNE, Zekri ARN. Expression of MMTV-like env gene in Egyptian breast cancer patients. Egypt J Med Microbiol. 2013;22(2):67-72. doi:10.12816/ 0004943

64. Shariatpanahi S, Farahani N, Salehi AR, Salehi R. High prevalence of mouse mammary tumor virus like gene sequences in breast cancer samples of Iranian women. Nucleosides Nucleotides Nucleic Acids. 2017;36(10):621-630. doi:10.1080/15257770.2017.1360498

65. Lawson. JS, Tran. DD, Carpenter. E, et al. presence of mouse mammary tumour-like virus gene sequences may be associated with morphology of specific human breast cancer. J Clin Pathol. 2006;59(12):1287-1292. doi:10.1136/jcp.2005.035907

66. Hachana M, Trimeche M, Ziadi S, et al. Prevalence and characteristics of the MMTV-like associated breast carcinomas in Tunisia. Cancer Lett. 2008;271(2):222-230. doi:10.1016/j.canlet.2008.06.001

67. Etkind P, Du J, Khan A, Pillitteri J, Wiernik PH. Mouse mammary tumor virus-like env gene sequences in human breast tumors and in a lymphoma of a breast cancer patient. Clin Cancer Res. 2000;6 (4):1273-1278. 
68. Motamedifar M, Saki M, Ghaderi A. Lack of association of mouse mammary tumor virus-like sequences in Iranian breast cancer patients. Med Princ Pr. 2012;21:244-248. doi:10.1159/000334572

69. Tawfik AM, Kassem BEB, Ayoub A, El-baseer MAA. Search for murine mammary tumor virus-like sequences in Egyptian females breast cancer. Am J Med Med Sci. 2015;5(5):223-226. doi:10.5923/j. ajmms.20150505.06

70. Lawson JS, Glenn WK. Multiple oncogenic viruses are present in human breast tissues before development of virus associated breast cancer. Infect Agent Cancer. 2017;12(1):1-8. doi:10.1186/s13027017-0165-2

71. Park DJ, Southey MC, Giles GG, Hopper JL. No evidence of MMTV-like env sequences in specimens from the Australian Breast Cancer Family Study. Breast Cancer Res Treat. 2011;125:229-235. doi:10.1007/s10549-010-0946-4

72. Kamal SM, Makki RF, Hammoudi DA. Mouse Mammary Tumor Virus (MMTV) like sequence in breast cancer of Egyptian women. Int J Canc Prev. 2005;2(2):109-115.
73. Pao CC, Lin SS, Lin CY, Maa JS, Lai CH, Hsieh TT. Identification of human papillomavirus DNA sequences in peripheral blood mononuclear cells. Am J Clin Pathol. 1991;95(4):540-546. doi:10.1093/ ajcp/95.4.540

74. Foresta C, Bertoldo A, Garolla A, et al. Human papillomavirus proteins are found in peripheral blood and semen $\mathrm{Cd} 20+$ and $\mathrm{Cd} 56$ + cells during HPV-16 semen infection. BMC Infect Dis. 2013;13 (1):1-10. doi:10.1186/1471-2334-13-593

75. Chen. A, Keleher A, Kedda MA, Spurdle AB, McMillan NAJ, Antonsson A. Human papillomavirus DNA detected in peripheral blood samples from healthy Australian male blood donors. $\mathrm{J}$ Med Virol. 2009;81(10):1792-1796. doi:10.1002/jmv.21592

76. Lawson JS, Glenn WK, Salyakina D, Delprado W, Davidson B, Lawson JS. Human papilloma viruses and breast cancer. Front Oncol. 2015;5(December):1-12. doi:10.3389/fonc.2015.00277

77. Polansky H, Schwab H. How latent viruses cause breast cancer: an explanation based on the microcompetition model. Bosn J Basic Med Sci. 2019;19(3):221-226. doi:10.17305/bjbms.2018.3950
Infection and Drug Resistance

\section{Publish your work in this journal}

Infection and Drug Resistance is an international, peer-reviewed openaccess journal that focuses on the optimal treatment of infection (bacterial, fungal and viral) and the development and institution of preventive strategies to minimize the development and spread of resistance. The journal is specifically concerned with the epidemiology of
Dovepress

antibiotic resistance and the mechanisms of resistance development and diffusion in both hospitals and the community. The manuscript management system is completely online and includes a very quick and fair peerreview system, which is all easy to use. Visit http://www.dovepress.com/ testimonials.php to read real quotes from published authors. 